\title{
Introduction: Teaching for Critical Consciousness at the Intersection of Critical Media Literacy and Hip Hop Education
}

\author{
Daren A. Graves \\ Associate Professor, Simmons University, Boston, MA, USA \\ daren.graves@simmons.edu \\ Lauren Leigh Kelly \\ Assistant Professor of Urban Social Justice Teacher Education, Department \\ of Learning and Teaching Rutgers, the State University of New Jersey, \\ New Brunswick, New Jersey, USA \\ lauren.kelly@gse.rutgers.edu
}

Sherell A. McArthur

Assistant Professor, Department of Educational Theory and Practice, University of Georgia, Athens, GA, USA

sherell.mcArthur@uga.edu

Hip Hop Education as Site for Critical Consciousness Development

In the 1970s, Hip Hop emerged as a form of cultural expression that belied overly optimistic master narratives about racial and class progress being espoused in light of civil rights legislation and other social and political gains enabled by the Civil Rights Movement and the Black Freedom Struggle (Rose, 1994). The vast array of Hip Hop's cultural features gave its producers a variety of means or modalities to practice intellectual, embodied, and spiritual behaviors and dispositions to disrupt this narrative and to develop counter-narratives. As outlined by Chang (2005), Hip Hop culture is comprised of at least four key tenets; emceeing (the oral traditions of Hip Hop), dj'ing (the instrumental traditions of Hip Hop), breakin' (sometimes called b-boyin'/b-girlin'; the kinesthetic/aesthetic traditions of Hip Hop), and graffiti (the visual art traditions of Hip Hop). "Knowledge of self" is often considered to be the fifth tenet of Hip Hop, where the other four elements come together help cultural producers and consumers develop a critical view of one's self, their communities, and the larger sociopolitical context (Chang, 2005; Love, 2013). In this 
regard, Hip Hop served as a major vector through which folks of color became politicized around race and racism in the "post-Civil Rights era" (Chang, 2005; Dimitriadis, 2009).

While Perry (2004) argues that Hip Hop music and culture definitely merit a critical analysis through the lens of a corporatized commodification and the potentially negative impacts this can have on youth development, she also urges us to see Hip Hop as an important site of resistance that can "vociferously critique white supremacy, classism, and racial exploitation" (p. 28). Perry argues that, using subversive discourse and aesthetic features rooted in the traditions of the Black Liberation Movement, Hip Hop music and culture can help youth of color construct identities that push back against deficit-oriented social constructions of minoritized race groups, create counter-narratives to notions of a "post-racial" society, and build political consciousness that orient youth to deconstruct oppressive social forces. Collins (2006) also posits that Hip Hop music and culture have the potential to serve as a site for Black feminists (among others) to construct and express an intersectional analysis of society that names and resists forms of misogyny that impact women of color in particular. In addition to being a culture of resistance, Morrell (2011) argues that the proximity of Hip Hop to the particularized lived experiences of youth of color makes it an especially useful cultural tool to analyze and critique their worlds and the social forces that shape them.

A growing body of scholarship suggests that youth of color can build resilience against the impacts of racism and other oppressive systems through the development of critical consciousness (e.g. Cammarota, 2007; Diemer \& Hsieh, 2008; Ginwright, 2010). Freire (1973) defines critical consciousness as the ability to recognize and analyze political, economic and social forces (often conferring differential power and privilege) shaping society and to take action against them. Expanding on this notion, Seider, Graves, El-Amin, et al. (2016) define critical consciousness as the ability to analyze, navigate, and challenge the oppressive social forces shaping people's lives. This perspective is informed by the research of Watts et al. (1999), who posited that one's capacity and commitment to challenge oppressive social forces through collective social action is influenced by the ability to analyze oppressive social forces as well as one's ability to navigate them using adaptive strategies (p. 259). Building upon Freire's work, Watts and Flanagan (2007) put forth a conceptual model of youth critical consciousness development by positing a bi-directional relationship between critical reflection and action. In this regard, increasing youths' ability to critically analyze their social conditions strengthens their commitment to challenging these conditions, and vice-versa. Watts and Flanagan (2007) also posit that meaningful opportunities to engage ("opportunity structures") in such reflection and action mediate the relationship between the two. 
In this regard, Hip Hop education represents a promising set of opportunity structures for the development of youths' critical consciousness. Dimitriadis (2001), Morrell and Duncan-Andrade (2005), Stovall (2006), and Kelly (2016) have demonstrated how Hip Hop education can provide youth with tools both to critically analyze the power structures that underpin societal conditions and to become more actively engaged in challenging oppressive societal conditions. More specifically, researchers have demonstrated how Hip Hop education can be a means to helping young people become more engaged citizens as well as to critically analyze issues of systemic and cultural racism (Clay, 2006; Love, 2013; Love, 2015; Pulido, 2009), sexism and misogyny (Love, 2012; Lindsey, 2015; Kelly 2016) and environmental justice (Cermak, 2012).

The Importance of Critical Media Literacy to Hip Hop Education

A critical literacy approach to education recognizes the power of language in shaping thought and transforming the world. Since schools serve as a significant site of youth development (Morris, 2016) and school curriculum is inherently raced, classed, and gendered (Baszile, 2006), academic classrooms present a powerful space for young people to develop critical literacies. For youth engaged in popular culture and digital media, a critical literacy framework allows them to examine the texts that surround them for sociopolitical understandings, especially pertaining to relationships of power. This form of critical media literacy (CML) empowers consumers to enact agency in the production and consumption of popular culture. One goal of this approach is to make visible the ways in which media can both construct and disseminate knowledge. Collins (2009) explains, “... controlling images are designed to make racism, sexism, poverty, and other forms of social injustice appear to be natural, normal, and inevitable parts of everyday life" (p. 77). As a result, even those who are from traditionally marginalized groups or who experience structural disempowerment may not recognize the source of this oppression and may be even less likely to challenge it. Through development of CML, young people can gain an understanding of the ways in which power is conferred and accessed in terms of wealth, education, and representation, and the impacts of structural inequity on their individual lives as students, consumers, and citizens (Morrell, 2004).

As one of the most influential forms of popular culture in the world today (Nguyen \& Ferguson, 2019), Hip Hop represents a site of cultural expression that is primed for its consumers and producers to understand the conferral of power and privilege. As mentioned above, Hip Hop has roots as a politicizing force aimed at surfacing a transformational analysis of power 
structures. Hip Hop culture has also been highly commodified by media conglomerates (Perry, 2004) and therefore can serve to reify oppressive structures as the aims of the media conglomerates undoubtedly stray away from empowering its consumers to interrogate and transform the socio-political status quo. Whether Hip Hop artists seek to intentionally pique consumers' interest in analyzing or transforming oppressive structures, or because the underlying structural conditions that facilitated the production of highly commodified Hip Hop merits a critical analysis by its consumers, a CML lens is essential in framing Hip Hop as a useful site for praxis towards critical consciousness development.

Since the mid 1990's, educators working within diverse subject areas have incorporated Hip Hop music and culture into classroom instruction (Hill \& Petchauer, 2013). In the past decade, this has occurred on a much larger scale, with an array of Hip Hop based curricular tools, academic classes, and professional development opportunities becoming increasingly available for students and educators. In his discussion of past and present developments within Hip Hop education, Hall (2017) explained, "teachers no longer need to be sold on why they should be using hip hop in the classroom; they want to be told how to use hip hop in the classroom" (p. 342). Indeed, educational institutions and non-profit organizations both within and outside of the United States have established regular conferences designed to train educators in using Hip Hop in the classroom as a culturally sustaining or culturally relevant practice[1]. Hip Hop education has also become increasingly visible in mainstream media through television spotlights on K-12 educators who use Hip Hop to increase student engagement and academic achievement in urban schools (Simon, 2017).

As it becomes more visible and popular, Hip Hop education can become more vulnerable to be applied in ways that do not serve the goals of critical consciousness. Petchauer (2011) shed light on the ways that, even with fervent Hip Hop fans, utilizing Hip Hop may not automatically lead one on a path to critical consciousness. Petchauer reminds us that Hip Hop has many elements, that Hip Hop fans may be particularly drawn to one of those elements, and their connections to those elements may not easily result in their desire to analyze underlying oppressive structures. Another potential pitfall in using Hip Hop education as a means to develop critical consciousness can lie in the educator's disingenuous application of Hip Hop to the learning process. If the educator superficially introduces features of Hip Hop culture because they assume it will intrinsically motivate students, it might actually result in an exacerbation of low motivation and engagement (Irby and Hall, 2011). 
This special issue calls for the application of a CML lens to the use of Hip Hop education as a means to develop critical consciousness. Morrell (2008) describes that critical media literacy pedagogy should give learners the skills and knowledge to critically consume and produce media. In this model, learners work with educators to examine relevant new media and interrogate the underlying power structures made evident through on-screen representations and off-screen production. Fueled with this knowledge, Morrell (2008) argues that learners then need to be empowered by the possibilities available through technology to create and disseminate their own, more authentically representative, media. By applying a CML lens to Hip Hop education, learners are positioned to interrogate oppressive structures, develop skills and dispositions that lead to a sense of agency, and take actions to author worlds with liberative possibilities.

A Preview of the Work in this Special Issue

This special issue illuminates the possibilities of critical consciousness development at the intersection of critical media literacy and Hip Hop education. What will follow are five papers outlining seven practitioners' innovative approaches to engaging in this work and the significant questions that emerge from critical approaches to Hip Hop education.

Lauren Leigh Kelly will show us how critical Hip Hop literacy practices can impact young folks' sociopolitical development, particularly their analysis of oppressive social forces. Kelly's paper also sheds light on the challenges and possibilities of doing this work in racially diverse classrooms and schools. Recognizing the racialized trauma that Black boys and men endure and the proximity of Hip Hop to their lived realities, Asif Wilson and Daunte Henderson speak to the ways that rap music can serve as a pedagogical tool to help young folks heal from this trauma. Wilson and Henderson illustrate how integrating a Critical Race Praxis orientation can help young folks of color analyze oppressive structures while simultaneously building a sense of critical hope. Crystal Leigh Endsley and Anthony Keith Jr. explore the possibilities of "Blackout Poetry" as a methodology to surface a means to resist and transform identities that are often bound and informed by oppressive systems. Employing a critical Hip Hop literacies lens, Endsley and Keith outline an innovative process and methodology that culminate in spoken word performances that serve to help learners affirm their contested identities while also embodying resistance to oppressive forces. Exploring the fertile ground of Out of School Time programs, 
Michael Dando demonstrates how Hip Hop education can help reframe how we conceive of Makerspaces and "Maker" identities. With the goal of creating culturally sustaining makerspaces, Dando shows how Hip Hop can help us expand our notions of where makerspaces have existed and can exist. The paper also shows us how these newly conceived makerspaces can help young folks of color be actively engaged in social justice art as a means to make meaning of and resist against oppressive forces. Esther Nam foregrounds the social media context that young folks are navigating and how this context can send powerful and problematic messages about race and racism. By employing critical media literacy and critical Hip Hop pedagogy lenses, Nam argues that educators can help young folks critically analyze oppressive narratives in the social media space and even utilize these digital practices to disseminate counternarratives.

Our goal in this special issue is to support educators in developing innovative and culturally sustaining ways to help young folks analyze, navigate, and/ or challenge the oppressive forces that can shape opportunities in their lives. Furthermore, our aim is to show how a critical application of Hip Hop education, especially as it pertains to current iterations of Hip Hop in young people's lives, is particularly effective at positioning young folks to develop critical consciousness. By applying critical pedagogy and literacies frames as we teach through Hip Hop, educators and practitioners can tap into young folks' vast potential to think, create, and act in ways that unearth a new world of possibilities in the face of the current and sociohistorical contexts that seek to constrain their futures.

\section{References}

Baszile, D. T. (2006). Rage in the interests of black self: Curriculum theorizing as dangerous knowledge. JCT, 22(1), 89.

Cammarota, J. (2007). A map for social change: Latino students engage a praxis of ethnography. Children Youth and Environments, 17(2), 341-353.

Cermak, M. (2012). Teaching a Hip-Hop Ecology. Contexts, 11(3), 76-79.

Chang, J. (2005). Can't stop won't stop: A history of the hip-hop generation. St. Martin's Press.

Clay, A. (2006). "All I Need Is One Mic": Mobilizing Youth for Social Change in the PostCivil Rights Era. Social Justice, 33(2), 105-121.

Collins, P. H. (2006). From Black power to hip hop: Racism, nationalism, and feminism. Temple University Press. 
Collins, P. H. (2009). Black feminist thought: Knowledge, consciousness, and the politics of empowerment. Routledge.

Diemer, M. A., \& Hsieh, C. A. (2008). Sociopolitical development and vocational expectations among lower socioeconomic status adolescents of color. The Career Development Quarterly, 56(3), 257-267.

Dimitriadis, G. (2001). Performing identity/performing culture: hip hop as text, pedagogy, and lived practice. New York: P. Lang.

Dimitriadis, G. (2009). Performing identity/performing culture: Hip hop as text, pedagogy, and lived practice (Vol. 1). Peter Lang.

Hall, H. B. (2017). Deeper than rap: Expanding conceptions of hip-hop culture and pedagogy in the English language arts classroom. Research in the Teaching of English, $51(3), 341$.

Hill, M. L., \& Petchauer, E. (Eds.). (2013). Schooling hip-hop: Expanding hip-hop based education across the curriculum. Teachers College Press.

Ginwright, S. A. (2010). Peace out to revolution! Activism among African American youth: An argument for radical healing. Young, 18(1), 77-96.

Irby, D. J., \& Hall, H. B. (2011). Fresh faces, new places: Moving beyond teacher-researcher perspectives in hip-hop-based education research. Urban Education, 46(2), 216240.

Freire, P. (1973). Education for critical consciousness (Vol. 1). Bloomsbury Publishing.

Kelly, L. L. (2016). "You Don't Have to Claim Her" Reconstructing Black Femininity Through Critical Hip-Hop Literacy. Journal of Adolescent \& Adult Literacy, 59(5), 529-538.

Lindsey, T. B. (2015). Let me blow your mind: Hip hop feminist futures in theory and praxis. Urban Education, $50(1), 5^{2-77}$.

Love, B. (2012). Hip hop's li'l sistas speak: Negotiating hip hop identities and politics in the new South (Counterpoints: studies in the postmodern theory of education, v. 399). New York: Peter Lang.

Love, B. L. (2013). "Oh, they're sending a bad message": Black males resisting and challenging Eurocentric notions of Blackness within hip hop and the mass media through critical pedagogy. International Journal of Critical Pedagogy, 4(3), 24-39.

Love, B., \& Petchauer, E. (2015). What Is Hip-Hop-Based Education Doing in Nice Fields Such as Early Childhood and Elementary Education? Urban Education, 50(1), 106-131.

Morrell, E. (2004). Linking literacy and popular culture: Finding connections for lifelong learning. Christopher-Gordon Publishers.

Morrell, E., \& Duncan-Andrade, J. (2005). Popular culture and critical media pedagogy in secondary literacy classrooms. International Journal of Learning, 12(1), 11.

Morrell, E. (2008). Critical literacy and urban youth. New York: Routledge. 
Morrell, E. (2011). Critical approaches to media in urban English language arts teacher development. Action in Teacher Education, 33(2), 157-171.

Morris, M. (2016). Pushout: The criminalization of Black girls in schools. The New Press.

Nguyen, J., \& Ferguson, G. M. (2019). A Global Cypher: The Role of Hip Hop in Cultural Identity Construction and Navigation for Southeast Asian American Youth. New directions for child and adolescent development, 2019(164), 99-115.

Perry, I. (2004). Prophets of the hood: Politics and poetics in hip hop. Duke University Press.

Petchauer, E. (2011). Knowing what's up and learning what you're not supposed to: Hiphop collegians, higher education, and the limits of critical consciousness. Journal of Black Studies, 42(5), 768-790.

Pulido, I. (2009). "Music fit for us minorities": Latinas/os' Use of Hip Hop as Pedagogy and Interpretive Framework to Negotiate and Challenge Racism. Equity \& Excellence in Education: Hip Hop and Social Justice Education, 42(1), 67-85.

Rose, T. (1994). Black Noise: Rap Music and Black Culture in Contemporary America. Wesleyan University Press: Published by University Press of New England.

Seider, S., Graves, D., El-Amin, A., Clark, S., Soutter, M., Tamerat, J., ... \& Sklarwitz, S. (2016). Preparing adolescents attending progressive and no-excuses urban charter schools to analyze, navigate, and challenge race and class inequality. Teachers College Record, $118(12),{ }^{-}-54$.

Simon, M. D. (2017), "My mic sounds nice: Rapping lesson plans is nothing new, $N B C$ News, 22 September, available at https://www.nbcnews.com/news/nbcblk/my-mic -sounds-nice-rapping-lessons-plans-nothing-new-n775366.

Stovall, D. (2006). We can relate: Hip-hop, critical pedagogy, and the secondary classroom. Urban Education, 41, 585-602.

Watts, R. J., \& Flanagan, C. (2007). Pushing the envelope on youth civic engagement: A developmental and liberation psychology perspective. Journal of Community Psychology, 35, 779-792.

Watts, R. J., Griffith, D. M., \& Abdul-Adil, J. (1999). Sociopolitical development as an antidote for oppression - theory and action. American Journal of Community Psychology, 27(2), 255-271. 